ZOOLOGIA 28 (6): 747-754, December, 2011

doi: $10.1590 /$ S1984-46702011000600007

\title{
Conquering Brazil: the invasion by the exotic gekkonid lizard Hemidactylus mabouia (Squamata) in Brazilian natural environments
}

\author{
Carlos Frederico D. Rocha'1,3; Luciano A. Anjos² \& Helena G. Bergallo \\ ${ }^{1}$ Departmento de Ecologia, Instituto de Biologia, Universidade do Estado do Rio de Janeiro. Rua São Francisco Xavier 524, \\ Maracanã, 20550-019, Rio de Janeiro, RJ, Brazil. \\ ${ }^{2}$ Departmento de Parasitologia, Instituto de Biociências, Universidade Estadual Paulista. 18618-000 Botucatu, SP, Brazil. \\ ${ }_{3}^{3}$ Corresponding author: cfdrocha@uerj.br
}

\begin{abstract}
In this study we review the records regarding occurrence of Hemidactylus mabouia Moreau De Jonnès, 1818 in Brazil, looking for records of the species in natural habitats, in order to assess the present status of this gecko as an exotic or invasive alien species in the country. We surveyed the available records of $H$. mabouia living in natural conditions, considering secondary data obtained from the literature, supplemented with original field records obtained by the authors during fieldwork. We found a total of 36 records in the literature and/or field records reporting the occurrence of $\mathrm{H}$. mabouia in natural habitats in 36 different localities in 13 Brazilian states. The states presenting a higher number of records were Rio de Janeiro (seven), Bahia, São Paulo (six), and Espírito Santo (five different areas). We show that the invasion of Brazilian natural habitats by $H$. mabouia has taken place for some decades. Presently we have consistent records that it has invaded natural habitats in 13 Brazilian states. This suggests thatit is important to start monitoring $H$. mabouia in order to measure the rate and effectiveness of its establishment in natural habitats in Brazi and also to evaluate the potential negative effects of this invasion on sympatric species.
\end{abstract}

KEY WORDS. Exotic species; invasive lizard; monitoring of species; open habitat invasion; status of invasion.

Hemidactylus mabouia Moreau De Jonnès, 1818 is an exotic (African) species which has been introduced and is successfully established in the New World, having colonized many countries in South America (including Brazil) (VANzolini 1978, Anjos \& Rocha 2008a), Central America and the Caribbean (except Jamaica - Kluge 1969, Howard et al. 2001) and parts of North America. A recent phylogenetic study (CARRanza \& ARnold 2006) suggests that African lineages have naturally crossed the Atlantic at least twice and colonized the New World, sometimes with devastating consequences for other geckos. In North America this gekkonid has rapidly colonized extensive areas (Lawson et al. 1991, Butterfield et al. 1993, Meshaka et al. 1994, Meshaka 2000), causing niche displacement of two other exotic congeners, H. garnotti and H. turcicus (MeshaKa 1995, 2000).

Hemidactylus mabouia is a nocturnal lizard that can be commonly found in anthropic or perianthropic environments (VANzolini et al. 1980) in different Brazilian ecosystems (RochA et al. 2011) such as the Amazon forest, the Atlantic forest, the Cerrado (savannah-like vegetation areas of central Brazil), the Caatinga (the semi-arid areas of northeastern Brazil), the Restingas (coastal sand-dune habitats of Brazil) and on some islands off the Brazilian coast (VAnzolini 1968, 1978, VANZolin et al. 1980, Vitt 1986, Araújo 1991, Avila-Pires, 1995, Rocha et al, 2000, 2002, Anjos \& Rocha 2008a, Rocha \& Bergallo 2011). Most information regarding occurrence and/or ecological as- pects of this exotic species in Brazil comes from anecdotal/general field observations (VAnzolini et al. 1980, TeIXeIRA et al. 2003), from auto-ecological studies (e.g., Zamprogno \& Teixeira 1998, Rосна et al. 2002, Bonfiglio et al. 2006, Anjos et al. 2007, Rосна $\&$ Anjos 2007, Anjos \& Rocha 2008b) and from community studies (Araújo 1991, Vitt 1995, Rocha \& VRcibradic 1998, Hatano et al. 2001, Teixeira 2001, Almeida-Gomes et al. 2008).

Although $H$. mabouia has been usually considered an exotic species in Brazil, restricted to anthropic environments, recent evidence suggests that this species has already invaded some natural environments, which would change its status from exotic to invasive exotic. Here, we review the records regarding $H$. mabouia in Brazil, looking for registered cases of invasion of of natural environments by the species in orderto assess classify the present status of this gecko as exotic or as an invasive exotic species in Brazil.

\section{MATERIAL AND METHODS}

We surveyed the available records of occurrence of $H$. mabouia living in natural conditions, considering secondary data available from literature, supplemented with original field records from the authors obtained during several years of fieldwork, mostly in southeastern, but also in some southern, northeastern and Amazonian areas. We made an effort to check the 
widest array of available literature reporting herpetofaunal surveys in Brazil, as well as other more specific herpetofaunal studies (e.g., species-specific studies). For the purpose of the present study, we only considered secondary data that clearly mentioned microhabitat and/or habitat occupation by H. mabouia in a natural environment at the time the lizard was collected or registered. For each record, we took note of the following (when available): date and time of collection, locality, municipality and state, coordinates of the area, microhabitat used by the gecko, general environment, and the source of the record.

\section{RESULTS}

We found a total of 36 literature and/or field records (Tab. I) reporting the occurrence of $H$. mabouia in natural habitats in 36 different localities of Brazilian states (Tab. I, Fig. 1). Of these, 18 records (or 50\%) were in restinga and/or sand dune habitats, five (or 13.9\%) in Cerrado environments, five (or 13.9\%) in forests, five (or 13.9\%) in rocky islands, two (or 5.6\%) in coastal rock faces and one (or 2.8\%) in rock outcrops dominated by Cerrado vegetation. Most of these records are from the eastern Brazil (Figs 1-5). The states presenting a higher number of records were Rio de Janeiro (seven), Bahia, São Paulo (six), and Espírito Santo (five different areas), but we also recorded $H$. mabouia in natural areas in Santa Catarina, Paraná, Pernambuco, Rio Grande do Norte, Ceará, Piauí, Maranhão, Mato Grosso and Goiás (Tab. I, Fig. 1). We found no record of this gekkonid as an invader in the Brazilian Amazonian region, although it has been recorded in different localities as an exotic species in anthropic and perianthropic areas in this Biome (e.g., Vanzolini 1986, VitT 1996, VitT et al. 1998, Avila-Pires, 1995, VitT \& Zani 1998). Figures 2-5 show the spread of H. mabouia in natural habitats in Brazil registered in literature during the last 70 years.

\section{DISCUSSION}

Hemidactylus mabouia occurs as an exotic species in virtually all urban environments in Brazil (VANZOLINI 1968, ANjos \& Rocha 2008a, Dossiê Pernambuco 2009, Rocha et al. 2011). Our data indicate that during the first decades after its first record in the country (1945) the species was recorded as invasive in natural environments in the following states: Paraná, Rio de Janeiro, São Paulo, and Piauí (Figs 2-5). Presently, the states with most records of invasions are Rio de Janeiro [both in restinga habitats (Myers 1945, Araújo 1984, 1991, 1994, Freire 1996, Teixeira 2001, Rocha et al. 2004, Carvalho et al. 2007) and in Evergreen Forest (CARvalho et al. 2007, Almeida-Gomes et al. 2008)]; Bahia (in restinga areas, DiAs \& Rocha 2005), in the dunes of the São Francisco River (RoDRIGUEs 1996) and in the insular environment of the Abrolhos archipelago (Rocha et al. 2002); Ceará (in Cerrado and Cerradão habitats, Ribeiro et al. 2008); São Paulo [in ruderal fields (Rocha \& ANJos 2007) and in continental islands (VANZOLINI 1968, Duarte et al. 1995, VRcibradic \& Rocha 2005)], and in

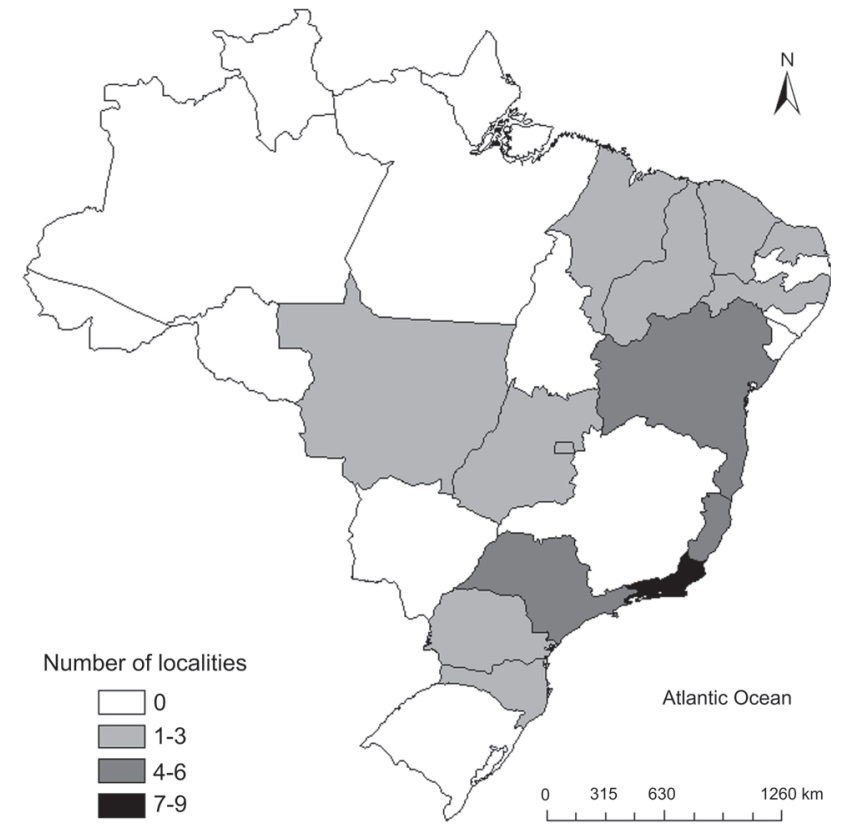

Figure 1. Map showing for each state of Brazil, the number of records of occurrence of the exotic gekkonid lizard Hemidactylus mabouia as an invader species in natural environments. The gradation of gray color intensities indicates the number of records for each particular state.

Pernambuco, in the Fernando de Noronha archipelago (RochA et al. 2009) (Figs 1-5). The spread of H. mabouia in nature, as extracted from the literature, shows that most invasions are concentrated in the eastern part of Brazil. This may be partially due to the fact that most studies are carried out in this part of Brazil and also due to the capacity of the species to invade open habitats such as restinga and cerrado (Rocha \& Bergallo 2011). The data show that this gecko has already invaded different types of open (and closed) natural environments in different regions of Brazil, including continental and insular areas. The first records of $H$. mabouia in natural habitats in Brazil we are aware of were provided by MYers (1945) for a coastal restinga and beach habitats of Rio de Janeiro and Paraná states.

The invasion of exotic species is considered an important cause of loss of biodiversity in protected areas and on oceanic islands (GISP 2005, Ziller \& Zalba 2007). The invasion of $H$. mabouia in the New World areas has resulted in negative impacts on populations of other native geckos (CARRANZA \& ARNOLD 2006 and references therein). This is an indication that the monitoring of the possible expansion of the species in natural environments in Brazil is of strategic importance. The events reported here regarding the invasion of natural environments by $H$. mabouia show that invasion of natural environments in Brazil by this species has taken place at least since 1945 and is steadily increasing, becoming more intense starting in 1980. In most areas in Brazil, the 

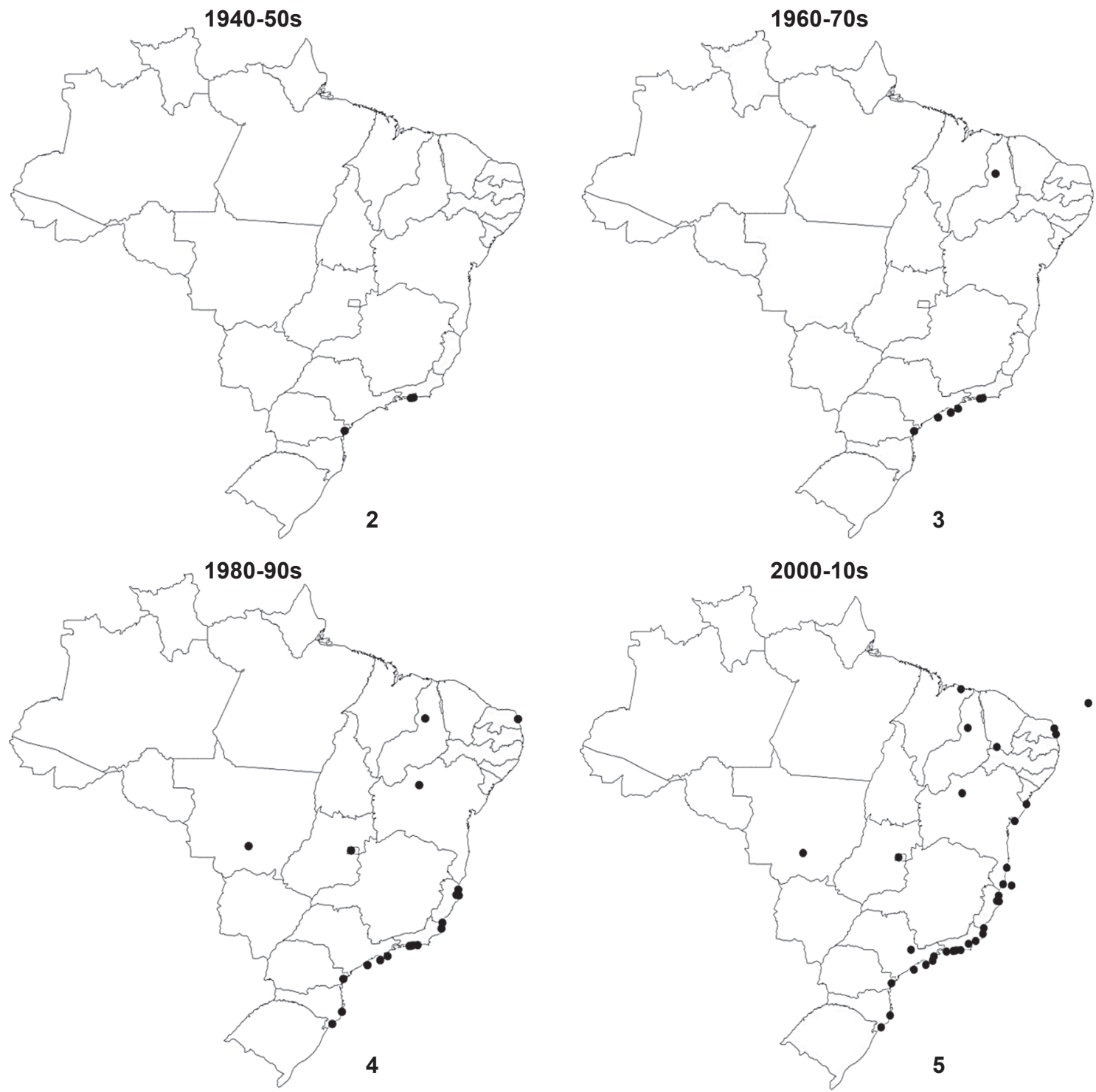

Figures 2-5. The spread of Hemidactylus mabouia in natural habitats in Brazil in the last 70 years based on records available in literature. The maps show (2) records of 1940 to 1959, and (3-5) the accumulation of records in the following decades.

species still remains restricted to urban or periantropic environments, although it is possible that it can change its status from exotic to invasive exotic in these areas in the near future. This change from exotic to invader can be even more critical in island habitats, which are fragile environments and tend to have comparatively lower diversity and richness of fauna.

The data available suggest that the invasion by $H$. mabouia is facilitated in open environments that have a high incidence of solar radiation at the ground level, such as restinga and cerrado habitats. For instance, in some forested Atlantic rainforest areas of Ilha Grande, no record of invasion by H. mabouia has been obtained, even after considerable efforts to find it during herpetological studies carried out during decades (RосHA et al. 2009), or as part of an extensive survey along existing trails in the island (Rocha \& Bergallo 2011). Similarly, there are still no reported cases of invasion of natural environments by $\mathrm{H}$. mabouia in extensive portions of the Amazon rain forest, although the Amazon forest encloses not only the largest territorial area but also constitutes one of the regions of Brazil with the largest number of available studies on herpetofauna (e.g., VAnzolins 1986, Duellman 1987, Martins 1991, Vitt 1996, VitT et al. 1998, 2008, VITT \& ZANI 1998). 
Table I. Summary of the existing literature records of occurrence of the exotic gekkonid lizard Hemidactylus mabouia as an invader species in some natural environments (including locality and State) in Brazil. ERB = Unpublished records of Expedição Restingas Brasileiras Unpublish Record; (?) indicates that information on microhabitat was not provided.

\begin{tabular}{|c|c|c|c|}
\hline Environment/Site & Microhabitat & Locality/State & Source \\
\hline \multicolumn{4}{|l|}{ Restinga and Sand Dune habitats } \\
\hline Barra de Maricá & On bromeliads & Maricá, RJ & ARAújo $(1984,1991)$ \\
\hline Grussaí & On bromeliads & Campos dos Goytacazes, RJ & $\begin{array}{l}\text { ERB CFD Rocha leg., 20/XI/1999, Reg } \\
\text { No. } 341\end{array}$ \\
\hline Gávea Beach (= São Conrado Beach) & On Fourcroya gigantea leaves & Rio de Janeiro, RJ & MYERS (1945) \\
\hline Restinga Sernambetiba & On Fourcroya gigantea leaves & Rio de Janeiro, RJ & MYERS (1945) \\
\hline Neves & On bromeliads & Presidente Kennedy, ES & ARAúJo (1994) \\
\hline Campo Nativo of Paraju & On bromeliads & Linhares, ES & Rосна (1998) \\
\hline Guriri & On bromeliads \& on tree trunks & São Mateus, ES & $\begin{array}{l}\text { TEIXEIRA (2001); ERB CFD Rocha leg. } \\
\text { 09/XI/1999 Reg. \#058 }\end{array}$ \\
\hline Costa Azul & $?$ & Jandaíra, BA & DiAs \& Rocha (2005) \\
\hline Abaeté & $?$ & Salvador, BA & DIAS \& Rocha (2005) \\
\hline Trancoso & $?$ & Porto Seguro, BA & DIAS \& ROCHA (2005) \\
\hline Nova Viçosa & $?$ & Nova Viçosa, BA & DIAS \& ROCHa (2005) \\
\hline Campos de dunas de Xique-Xique & On tree trunks & Ibiraba \& Queimadas, BA & RODRIGUES (1996) \\
\hline Dunes \& restinga habitats of Lençóis & Under logs/decomposing tree trunks & Barreirinhas/Santo Amaro, MA & MIRANDA (2007) \\
\hline Dunes \& restinga habitats of Natal & On bromeliads/leaf litter/tree trunks & Natal, RN & FREIRE (1996) \\
\hline Beach habitat south Paranaguá estuary & On Fourcroya gigantea leaves & Paranaguá, PR & MYERS (1945) \\
\hline \multicolumn{4}{|l|}{ Cerrado (Savannah-like vegetation) } \\
\hline Cerrado of Brasília & $?$ & Brasília, DF & Araújo (1992) \\
\hline Cerrado of the Chapada & $?$ & Chapada dos Guimarãres, MT & ARAújo (1992) \\
\hline Cerrado and Cerradão of the Chapada & $?$ & Chapada do Araripe, CE & RIBEIRO et al. (2008) \\
\hline \multicolumn{4}{|l|}{ Forested environments } \\
\hline Forest of Marambaia & On tree trunks & Rio de Janeiro, RJ & CARVALHo et al. (2007) \\
\hline Ombrophilous forest & On tree trunks & Casimiro de Abreu, RJ & AlmeidA-Gomes et al. (2008) \\
\hline Forest at Fazenda Brunoro & $?$ & Venda Nova do Imigrante, ES & SAMPAIO et al. (2007) \\
\hline Forest of Ilha Anchieta & $?$ & Ubatuba, SP & СıccH et al. (2009) \\
\hline Massaguassu & $?$ & Caraguatatuba, SP & Instituto Horus \\
\hline \multicolumn{4}{|l|}{ Rocky islands } \\
\hline Abrolhos Archipelago & On \& under rocks & Caravelas, BA & RocHA et al. (2002) \\
\hline Fernando de Noronha Archipelago & On rocks and on tree trunks & Fernando de Noronha, PE & Rocha et al. (2009) \\
\hline Alcatrazes Archipelago & On clumps of bromeliads; in forests & São Sebatião, SP & VANZOLINI (1968), MARQUES et al. (2002a) \\
\hline Queimada Grande Island & On clumps of bromeliads; in forests & Itanhaém, SP & $\begin{array}{l}\text { VANZOLINI (1968) DUARTE et al. (1995) } \\
\text { MARQUES et al. (2002b) }\end{array}$ \\
\hline Ilha dos Búzios island & On clumps of bromeliads & Ilhabela, SP & VANZOLINI (1968) \\
\hline \multicolumn{4}{|l|}{ Coastal Rocky Hills } \\
\hline Coastal Rocky Hills & On hill surface at seaside & Araranguá, SC & LeMA (1994) \\
\hline Coastal Rocky Hills & On hill surface at seaside & Garopaba, SC & LEMA (1994) \\
\hline \multicolumn{4}{|l|}{ Rock outcrop } \\
\hline Fazenda Manga & On rock blocks surface & Valinhos, SP & $\begin{array}{l}\text { ROCHA \& ANJOS (2007), ANJOS \& ROCHA } \\
\text { (2008b) }\end{array}$ \\
\hline
\end{tabular}


One interesting feature that arises from the records available regarding invasion of natural environments by $\mathrm{H}$. mabouia in Brazil is the lack of records from the state of Minas Gerais (which is clearly depicted in Fig. 1), although reptiles from this state, including considerations on exotic ones, have been recently surveyed (BérniLs et al. 2009). This is one of the largest states in Brazil and, according to our data, the states surrounding it have records of invasion of natural environments by $H$. mabouia. At this point we do not know to which extent this gap results from a real absence of invasion of natural environments by this gecko up to now, or if it is caused by a lack of reports on the occurrence of the species in natural environments in the state. We strongly recommend that when researchers find $H$. mabouia during herpetological fieldwork, they describe, in as much detail as possible, the habitat and microhabitat used by the gecko and the date and time of the event. Also, we do not know whether the predominance of records of the gecko in natural environments in coastal states of Brazil might be a by-product of the fact that human colonization of the country started from the coast towards inland regions.

Data available indicate that, in natural environments, the main microhabitats used by H. mabouia are bromeliads (on green leaves or under the dried leaves of the bromeliad base) and on tree trunks where individuals tend to remain under the bark of the trees. Eggs (and in some cases also hatched egg shells) have been found among dried leaves at the base of bromeliads, both isolated and in groups (C.F.D. Rосна pers. obs. in Praia das Neves and in Guriri restingas, Espírito Santo). The finding of hatched eggshells suggests successful completion of the reproductive cycle of this gecko in nature in those restingas.

Although $H$. mabouia is a characteristically nocturnal species, in the natural areas where it was recorded as an invader individuals have been found to be active also during the day (e.g., HATANo et al. 2001). For example, in a restinga habitat, which was actively searched for different species of diurnal lizards during different periods of the day, active individuals of $H$. mabouia have been recorded, especially in the afternoon (from 14:00 to 18:00 pm) (HATANo et al. 2001). This shows that in that open habitat the gecko extended its activity to daytime, potentially interacting and sharing space and food resources not only with some nocturnally native vertebrates (e.g., frogs, some lizards, small mammals), but alsowith diurnal ones. Also, the occurrence of $H$. mabouia as prey of some snakes - Thamnodynastes strigilis

(Thunberg, 1787) and Oxyrhopus guibei Hoge \& Romano, 1978, Colubridae - and a lizard species - Tropidurus torquatus (Wied, 1820), Tropiduridae - in the restinga habitat of Barra de Maricá in Rio de Janeiro (Rocha \& VRCibradic 1998) is another consistent evidence of this invader species interacting in nature with sympatric native vertebrates. A similar trend can be inferred from the H. mabouia population at the Alcatrazes and Queimada Grande islands, off the coast of São Paulo, where this gecko is occasional prey for the local insular pitvipers, Bothrops alcatraz (= Bothropoides alcatraz (Marques, Martins \& Sazima, 2002)
(MARques et al. 2002a) and Bothrops insularis (Amaral, 1921) (DUARTE et al. 1995), respectively. Regarding the relationship with parasites, after the process of colonization, a well established invader species might harbor the local parasitic fauna (CRISCIONE $\&$ FonT 2001). Concerning the establishment and the interaction with native lizards within a community, another evidence of $H$. mabouia entering the natural system was the acquisition of parasitic fauna from the local sympatric lizards in a rock outcrop area at Valinhos in state of São Paulo (ANjos et al. 2005).

The data available suggest that invasion of $H$. mabouia in forested environments seems to be less favored than in open habitats (only $14.8 \%$ in forested habitats and $85.2 \%$ in open habitats), an idea to be evaluated. We do not know to which extent this might be caused by more restricted thermal characteristics of forested environments compared with more open habitats (such as restingas, cerrado, and coastal rocky islands), or whether it might be due to the comparatively higher humidity of forests that would not be favorable to this nocturnal gekkonid. Additionally, because this gecko has an African origin and is possibly adapted to open habitats (KLUGE 1969), it is expected to be found in open habitats in Brazil also.

Based on our data, the invasion of open Brazilian natural habitats by $H$. mabouia has already taken place since at least 1945 and presently we have consistent records of its invasion of nature for 13 Brazilian States. This suggests that, at this point, it is important to start monitoring $H$. mabouia species in order to measure the rate and effectiveness of the progress of its colonization of natural habitats in Brazil and also, of its potential negative effects imposed on sympatric species.

\section{ACKNOWLEDGEMENTS}

This study is part of the results of the project "Mapeamento e avaliação do status de invasão" (E-26.110.430/2007) of Fundação Carlos Chagas Filho de Amparo à Pesquisa do Estado do Rio de Janeiro - FAPERJ to HGB. It was also partially supported by grants from FAPERJ to CFDR and HGB through the "Programa Cientistas do Nosso Estado" (Process E-26/102.404/ 2009 and E-26/102.799/2008) and by the Conselho Nacional do Desenvolvimento Científico e Tecnológico - CNPq (processes $304791 / 2010-5$ and $470265 / 2010-8$ ) to CFDR and (Process 309527/2006-6) to HGB. We thank Davor Vrcibradic who kindly revised the manuscript offering helpful suggestions. The Instituto Biomas provided some logistic support for this study.

\section{LITERATURE CITED}

Almeida-Gomes, M.; D. Vrcibradic; C. Siqueira; M.C. Kiefer; T. Klaion; P. Almeida-Santos; D. Nascimento; C.V. Ariani; V.N.T. Borges-Junior; R.F. Freitas-Filho; M. Van Sluys \& C.F.D. RoCHA. 2008. Herpetofauna of an Atlantic rainforest area (Morro São João) in Rio de Janeiro State, Brazil. Anais da Academia Brasileira de Ciências 80: 291-300. 
Anjos, L.A. \& C.F.D. RochA. 2008a. The Hemidactylus mabouia Moreau de Jonnes, 1818 (Gekkonidae) lizard: an invasive alien species broadly distributed in Brazil. Natureza \& Conservação 6: 196-207.

Anjos, L.A. \& C.F.D. Rосна. 2008b. Hemidactylus mabouia, a fixed clutch size invader species: how do this gekkonid maximize their reproductive success? Iheringia, Série Zoologia, 98: 1-5.

Anjos, L.A.; C.F.D. Rocha; D. Vrcibradic \& J.J. Vicente. 2005. Helmints associated with the exotic lizard Hemidactylus mabouia in an area of rock outcrops in southeastern Brazil. Journal of Helminthology 79: 307-313.

Anjos, L.A.; W.O. Almeida; A. Vasconcellos; E.M.X. Freire \& C.F.D. Rocha. 2007. The Alien and Native Pentastomids Fauna of an Exotic Lizard Population from Brazilian Northeast. Parasitology Research 101: 627-628.

Araújo, A.F.B. 1984. Padrões de divisão de recursos em uma comunidade de lagartos de restinga, p. 327-342. In: L.D. Lacerda; D.S.D. Araújo; R. Cerqueira \& B. Turce (Eds). Restingas: origem, estrutura e processos. Niterói, CEUFF.

Araújo, A.F.B. 1991. Structure of a white sand dune lizard community of coastal Brazil. Revista Brasileira de Biologia 51 (4): 857-865.

Araújo, A.F.B. 1994. Comunidades de lagartos brasileiros, p. 5868. In: L.B. Nascimento; A.T. Bernardes \& G.A. Cotta (Eds). Herpetologia no Brasil 1. Belo Horizonte Pontifícia Universidade Católica de Minas Gerais, Sociedade Brasileira de Herpetologia.

Ávila-Pires, T.C.S. 1995. Lizards of Brazilian Amazonia (Reptilia: Squamata). Zoologische Verhandelingen 299 (1): 1-706.

Bérnils, R.S.; C.C. Nogueira \& V. Xavier-Da-Silva. 2009. Répteis, p. 251-278. In: M. Drummond; C.S. Martins; M.B. Greco \& F. VIERA (Eds). Biota Minas: diagnóstico do conhecimento sobre a biodiversidade no Estado de Minas Gerais - subsídio ao Programa Biota Minas Gerais. Belo Horizonte, Fundação Biodiversitas.

Bonfiglio, F; R.L. Balestrin \& L.H. Cappellari. 2006. Diet of Hemidactylus mabouia (Sauria, Gekkonidae) in urban area of southern Brazil. Biociencias 14 (2): 107-111.

Butterfield, B.P.; B. Hauge \& W.E. MeshaKa. 1993. The occurrence of Hemidactylus mabouia on the United States mainland. Herpetological Review 24 (3): 111-112

Carranza, S. \& E.N. Arnold. 2006. Systematics, biogeography, and evolution of Hemidactylus geckos (Reptilia: Gekkonidae) elucidated using mitochondrial DNA sequences. Molecular Phylogenetics and Evolution 38 (2): 531-545.

Carvalho, A.L.G.; A.F.B. Araújo \& H.R. Silva. 2007. Lagartos da Marambaia, um remanescente insular de Restinga e Floresta Atlântica no Estado do Rio de Janeiro, Brasil. Biota Neotropica 7: 1-5.

Cicchi, P.J.P.; H. Serafim; M.A. Sena; F.C. Centeno \& J. Jim. 2009. Herpetofauna em uma área de Floresta Atlântica na Ilha Anchieta, município de Ubatuba, sudeste do Brasil. Biota Neotropica 9: $1-12$.
Criscione, C.D. \& W.F. Font. 2001. The guest playing host: colonization of the introduced Mediterranean gecko, Hemidactylus turcicus, by helminth parasites in southeastern Louisiana. Journal of Parasitology 87: 1273-1278.

Dossiê Pernambuco. 2009. Contextualização Sobre Espécies Exóticas Invasoras. Recife, Centro de Pesquisas Ambientais do Nordeste, 63p.

Dias, E.J.R. \& C.F.D. Rocha. 2005. Os répteis nas restingas do Estado da Bahia: pesquisa e ações para sua conservação. Rio de Janeiro, Instituto Biomas press, 36p.

Duarte, M.R.; G. Puorto \& F.L. Franco. 1995. Abiological survey of the pitviper Bothrops insularis Amaral (Serpentes,Viperidae): an endemic and threatened offshoreisland snake of southeastern Brazil. Studies on Neotropical Fauna \& Environment 30: 113.

Duellman, W.E. 1987. Lizards in Amazonian rainforest community: resource utilization and abundance. National Geographic Research 3 (4): 489-500.

Freire, E.M.X. 1996. Estudo ecológico e zoogeográfico sobre a fauna de Lagartos (Sauria) das dunas de Natal, Rio Grande do Norte e da restinga de Ponta de Campina, Cabedelo, Paraíba, Brasil. Revista Brasileira de Zoologia 13 (4): 903-921.

GISP. 2005. A América do Sul invadida: a crescente ameaça das espécies exóticas invasoras. Nairobi, Programa Global de Espécies Invasoras (GISP), 80p.

Hatano, F.H.; D. VRCIBRADIC; C.A.B. Galdino; M. Cunha-Barros; C.F.D. Rocha \& M. VAN SLuYs. 2001. Thermal ecology and activity patterns of the lizard community of the restinga of Jurubatiba, Macaé, RJ. Revista Brasileira de Biologia 61 (2): 287-294.

Howard, K.G.; J.S. Parmerlee \& R. Powell. 2001. Natural history of the edificarian geckos Hemidactylus mabouia, Thecadactylus rapicauda, and Sphaerodactylus sputator on Anguilla. Caribbean Journal of Science 37: 285-288.

KLUGE, A.G. 1969. The evolution and geographical origin of the New World Hemidactylus mabouia-brookii complex (Gekkonidae, Sauria). Miscellaneous Publications Museum of Zoology, University of Michigan 138: 1-78.

Lawson, R.; P.G. Frank \& D.L. Martin. 1991. A gecko new to the United States Herpetofauna, with notes on geckoes of the Florida Keys. Herpetological Review 22 (1): 11-12.

Lema, T. 1994. Lista comentada dos répteis ocorrentes no Rio Grande do Sul, Brasil. Comunicações do

Museu de Ciência e Tecnologia da PUCRS, Série Zoologia, 7: 41-150.

Marques, O.A.V.; M. Martins \& I. Sazima. 2002a. A new insular species of pitviper from Brazil, with comments on evolutionary biology and conservation of the Bothrops jararaca group (Serpentes, Viperidae). Herpetologica 58 (3): 303-312.

Marques, O.A.V.; M. Martins \& I. Sazima. 2002b. A jararaca da Ilha da Queimada Grande. Ciência Hoje 31: 56-59.

Martins, M. 1991. The lizards of Balbina, Central Amazonia, Brazil: a qulitative analysis of resource utilization. Studies on Neotropical Fauna \& Environment 26 (3): 179-190. 
MeshaKa, W.E. 1995. Reproductive cycle and colonization ability of the mediterranean gecko (Hemidactylus turcicus) in southcentral Florida. Florida Science 58 (1): 10-15.

Meshaka, W.E. 2000. Colonization Dynamics of two exotic geckos (Hemidactulus garnotii and H mabouia) in Everglades National Park. Journal of Herpetology 34 (1): 63-168.

Meshaka, W.E.; B.P. Butterfield \& B. Hauge. 1994. Hemidactylus mabouia as an established member of the Florida herpetofauna. Herpetological Review 25 (2): 80-81.

MirandA, J.P. 2007. Ecologia e Conservação da Herpetofauna do Parque Nacional dos Lençóis Maranhenses, Maranhão, Brasil. Campinas, PhD Thesis, Universidade Estadual de Campinas, 139p. Available on line at: http://capesdw.capes.gov.br/ capesdw $/$ resumo.html idtese $=2007333003017010 \mathrm{P} 1$ [Accessed: 10/VI/2011].

Myers, G.S. 1945. A natural habitat of the house gecko (Hemidactylus mabouia) in Brazil. Copeia 1945 (2): 120.

Ribeiro, S.C.; F.S. Ferreira; S.V. Brito; G.G. Santana; W.L.S. Vieira; R.R.N. Alves \& W.O. Almeida. 2008. The squamata fauna of the Chapada do Araripe, Northeastern Brazil. Cadernos de Cultura e Ciência 1 (1): 67-75.

Rocha, C.F.D. 1998. Composição e Organização da Comunidade de Répteis da Área de Mata Atlântica da Região de Linhares, Espírito Santo, p. 869-881. In: Anais do VIII Seminário Regional de Ecologia 2. São Carlos, Universidade Federal de São Carlos.

Rocha, C.F.D. \& D. Vrcibradic. 1998. Reptiles as predators and as preys in a restinga habitat of Southeastern Brazil. Ciência \& Cultura 50 (5): 364-368.

Rocha, C.F.D. \& L.A Anjos. 2007. Feeding ecology of a nocturnal invasive alien lizard species, Hemidactylus mabouia Moreau de Jonnès, 1818 (Gekkonidae), living in an outcrop rocky area in southeastern Brazil. Brazilian Journal of Biology 67: 485-491.

Rocha, C.F.D. \& H.G. Bergallo. 2011. Occurrence and distribution of the exotic lizard Hemidactylus mabouia Moreau de Jonnès, 1818 in Ilha Grande, RJ, Brazil. Brazilian Journal of Biology 71 (2): 1-4.

Rocha, C.F.D.; D. Vrcibradic \& A.F.B. Araújo. 2000. Ecofisiologia de répteis de restingas brasileiras, p. 117-149. In: F.A. Esteves \& L.D. LACERDa (Eds). Ecologia de Restingas e Lagoas Costeiras. Rio de Janeiro, NUPEM-UFRJ.

Rocha, C.F.D.; G.F. Dutra; D. \& V.A. MenEzes. 2002. The terrestrial reptile fauna of the Abrolhos Archipelago: species list and ecological aspects. Brazilian Journal of Biology 62 (2): 285291.

Rocha, C.F.D.; M. Van Sluys; D. Vrcibradic; F.H. Hatano; C.A. Galdino; M. Cunha-Barros \& M.C. Kiefer. 2004. A Comunidade de Répteis da Restinga de Jurubatiba, p. 179-198. In: C.F.D. Rocha; F.A. Esteves \& F.R. Scarano (Orgs). Pesquisas Ecológicas de Longa Duração na Restinga de Jurubatiba: Ecologia, História Natural e Conservação. São Carlos, Rima Editora.
Rocha, C.F.D.; D. Vrcibradic; V.A. Menezes \& C. Ariani. 2009. Ecology and natural history of the easternmost native lizard species in South America, Trachylepis atlantica (Scincidae), from the Fernando de Noronha archipelago. Brazilian Journal of Herpetology 43 (3): 450-459.

Rocha, C.F.D.; H.G. Bergallo; M.A.S. Alves; M. Van Sluys; R. Mazzoni \& S.B. Santos. 2009. Fauna de ambientes interiores, p 163-246. In: C. Callado \& M. Bastos (Eds). O Ambiente da Ilha Grande. Rio de Janeiro, UERJ/CEADS.

Rocha, C.F.D.; H.G. Bergallo \& R. Mazzoni. 2011. Invasive Vertebrates in Brazil, p 53-103. In: D. Pimentel (Ed.). Economic and Environmental Costs of Alien Plant, Animal, and Microbe Species. New York, Taylor \& Francis, $2^{\text {nd }}$ ed.

Rodrigues, M.T. 1996. Lizards, snakes and amphisbaenians of the quaternary sand dunes of the Rio São Francisco: Bahia: Brazilian Journal of Herpetology 30 (4): 513-523.

Sampaio, F.D.F.; H. Rabello; T.M. Castro; L.U. Maiolli \& H.V.M. Barbosa. 2007. Levantamento da Ordem Squamata da Reserva Legal da Fazenda Brunoro Agro-Avícola em Venda Nova do Imigrante, Estado do Espírito Santo, p. 1-2. In: Anais do VIII Congresso de Ecologia do Brasil. São Paulo, Sociedade de Ecologia do Brasil. Available online at: http://www.sebecologia.org.br/viiiceb/pdf/831.pdf [Accessed: 06/XII/2011]

TeiXeIRA, R.L. 2001. Comunidade de lagartos da restinga de Guriri, São Mateus - ES, sudeste do Brasil. Atlântica 23: 77-84.

Teixeira, R.L.; D.G. Loss \& D. VRcibradic. 2003. Hemidactylus mabouia (Tropical House Gecko). Mortality. Herpetological Review 34: 368-369.

VANZolini, P.E. 1968. Lagartos Brasileiros da Família Gekkonidae (Sauria). Arquivos de Zoologia, São Paulo 17: 1-84.

VAnzolini, P.E. 1978. On South American Hemidactylus (Sauria, Gekkonidae). Papéis Avulsos de Zoologia, São Paulo 31 (20): 307-343.

VANZOLINI, P.E. 1976. On the lizards of cerrado-caatinga contact: evolutionary and zoogeographical implications (Sauria). Papéis Avulsos de Zoologia 29: 111-119.VAnzolini, P.E. 1986. Levantamento Herpetológico da área do Estado de Rondônia sob a influência da Rodovia BR 364. Brasília, Programa Polonoroeste, MCT, CNPq, 50p.

Vanzolini, P.E.; A.M.M. Ramos-Costa \& L.J. VitT. 1980. Répteis das Caatingas. Rio de Janeiro, Academia Brasileira de Ciências, 161p.

VITT, L.J. 1986. Reproductive Tactics of Sympatric Gekkonid Lizards with a Comment on the Evolutionary and Ecological Consequences of Invariant Clutch Size. Copeia 3: 773-786.

VITT, L.J. 1995. The Ecology of Tropical Lizards in the Caatinga of Northeast of Brazil. Occasional Papers of Oklahoma Museum of Natural History 1: 1-29.

VITT, L.J. 1996. Biodiversity of Amazonian Lizards, p. 89-108. In: A.C. GIBSON (Ed.). Neotropical Biodiversity and Conservation. Los Angeles, Mildred E. Mathias Botanical Garden,UCLA.

VitT, L.J. \& P.A. ZANi. 1998. Ecological relationships among sympatric lizards in a transitional forest in the northern Amazon of Brazil. Journal of Tropical Ecology 14: 63-86. 
VitT, L.J.; T.C.S. Avila-Pires; J.P. Caldwell \& V.R.L. Oliveira. 1998. The impact of individual tree harvesting on thermal environments of lizards in Amazonian rainforest. Conservation Biology 12: 654-664.

Vitt, L.J.; W.E. Magnusson; T.C.S. Avila-Pires \& A.P. Lima. 2008. Guia de lagartos da Reserva Adolfo Ducke. Amazônia Central. Manaus, Áttema Design Editorial, 175p.

VRcibradic, D. \& C.F.D. Rocha. 2005. Observations on the natural history of the lizard Mabuya macrorhyncha Hoge (Scin- cidae) in Queimada Grande Island, São Paulo, Brazil. Revista Brasileira de Zoologia 22 (4): 1185-1190.

Zamprogno, C. \& R.L. Teixeira. 1998. Hábitos Alimentares da Lagartixa de Parede Hemidactylus mabouia (Reptilia, Gekkonidae) da Planície Litorânea do Norte do Espírito Santo, Brasil. Revista Brasileira de Biologia 58 (1): 143-150.

ZILler, S.R. \& S. Zalba. 2007. Propostas de ação para prevenção e controle de espécies exóticas invasoras. Natureza \& Conservação 5 (2): 52-61.

Submitted: 18.VI.2011; Accepted: 08.XI.2011.

Editorial responsibility: Ana Lúcia da C. Prudente 